\title{
Sorafenib induces cathepsin B-mediated apoptosis of bladder cancer cells by regulating the Akt/PTEN pathway. The Akt inhibitor, perifosine, enhances the sorafenib-induced cytotoxicity against bladder cancer cells
}

\author{
Consuelo Amantini ${ }^{1}$, Maria Beatrice More $\mathrm{li}^{2,3}$, Matteo Santoni ${ }^{4}$, Alessandra Soriani ${ }^{3}$ \\ Claudio Cardinali ${ }^{2,3}$, Valerio Farfariello ${ }^{3}$, Anna Maria Eleuteri ${ }^{1}$, Laura Bonfili ${ }^{1}$, \\ Matteo Mozzicafreddo ${ }^{1}$, Massimo Nabissi ${ }^{2}$, Stefano Cascinu ${ }^{3}$, Giorgio Santoni ${ }^{2}$ \\ ${ }^{1}$ School of Biosciences and Veterinary Medicine, University of Camerino, Camerino, Italy \\ ${ }^{2}$ School of Pharmacy, Experimental Medicine Section, University of Camerino, Camerino, Italy \\ ${ }^{3}$ Department of Molecular Medicine, Sapienza University, Rome, Italy \\ ${ }^{4}$ Department of Medical Oncology, Polytechnic University of Marche, Ancona, Italy \\ Correspondence to: Giorgio Santoni, email: giorgio.santoni@unicam.it \\ Keywords: sorafenib, bladder cancer cells, cathepsin B, Akt, TKI, perifosine \\ Received: January 27, $2015 \quad$ Accepted: March 16, 2015 \\ Published: March 23, 2015
}

This is an open-access article distributed under the terms of the Creative Commons Attribution License, which permits unrestricted use, distribution, and reproduction in any medium, provided the original author and source are credited.

\section{ABSTRACT}

Sorafenib, a tyrosine kinase inhibitor, has been demonstrated to exert anti-tumor effects. However, the molecular mechanisms underlying its effects on bladder cancer remain unknown.

Here, we evaluated the mechanisms responsible for the sorafenib-induced antitumor effects on 5637 and T24 bladder cancer cells. We demonstrated that sorafenib reduces cell viability, stimulates lysosome permeabilization and induces apoptosis of bladder cancer cells. These effects are dependent by the activation of cathepsin $B$ released from lysosomes. The sorafenib-increased cathepsin B activity induced the proteolysis of Bid into tBid that stimulates the intrinsic pathway of apoptosis characterized by mitochondrial membrane depolarization, oxygen radical generation and cytochrome c release. Moreover, we found that cathepsin B enzymatic activity, induced by sorafenib, is dependent on its dephosphorylation via PTEN activation and Akt inactivation. Pretreatment with orthovanadate rescued bladder cancer cells from apoptosis. In addition, the Akt inhibitor perifosine increased the sensitivity of bladder cancer cells to sorafenib-induced cytotoxicity.

Overall, our results show that apoptotic cell death induced by sorafenib in bladder cancer cells is dependent on cathepsin B activity and involved PTEN and Akt signaling pathways. The Akt inhibitor perifosine increased the cytotoxic effects of sorafenib in bladder cancer cells.

\section{INTRODUCTION}

Sorafenib is an oral multi-target inhibitor of the Raf1 and B-Raf kinases, which are members of the Raf/MEK/ ERK signaling pathway. In bladder cancer (BC) cells, sorafenib has been found to induce apoptosis, however the cellular and molecular mechanisms responsible for the anti-tumor effects in $\mathrm{BC}$ cells remain at present unknown [1]. Sorafenib has been found to inhibit several receptor tyrosine kinases (RTKs) that are involved in neoangiogenesis and tumor progression, such as vascular endothelial growth factor receptors (VEGFR1-3), plateletderived growth factor receptors (PDGFR a and $b$ ), tyrosine protein kinase Kit (c-kit), fms-related tyrosine kinase 3 (Flt3), Colony stimulating factor 1 receptor (CSF-1R) and Rearranged during Transfection (RET) [2]. In vivo, sorafenib has been administered in phase II clinical trials to patients with urothelial carcinoma (UC) who had been 
treated with one prior chemotherapy regimen [3] and to patients with metastatic UC [4]. In addition, sorafenib has been administered in combination with cisplatin and gemcitabine to patients with node-negative transitional BC cells [5], but no objective responses have been detected to date. Chemotherapy of bladder cancers represents the mainstay of treatment and confers survival advantage. However, despite such advances, it remains disappointing because of its toxicity, reinforcing again the rationale for the discovery of new targeted therapeutic approaches [6].

The phosphoinositide 3-kinase/protein kinase B (PI3-K/Akt) pathway, frequently altered in BC, plays a key role in the regulation of cell proliferation, angiogenesis and cell survival and represents a potential therapeutic target $[7,8]$. In addition to targeting RTKs, sorafenib also affects the PI3-K/Akt pathways and their negative regulator, the lipid phosphatase and tensin homolog (PTEN) pathway. The activation of PI3K/Akt signaling mediates the acquired resistance to sorafenib in hepatocellular carcinoma (HCC) cells [9]; PTEN overexpression enhances the sensitivity of HCC cells to the anti-proliferative and pro-apoptotic effects of sorafenib [10]. Akt is up-regulated in many human cancers, including BC. Approximately 21\% of muscle-invasive BCs exhibit activating PI3K/Akt mutations, and another $30 \%$ display evidence of PTEN inactivation $[11,12]$. Stimulation of the PI3K/Akt/PTEN signaling pathway via aberrant RTK activity, which occurs by the reversible alteration of the phosphorylation state of specific tyrosine residues, results in the impairment of cell survival/ proliferative responses $[13,14]$. The RTK-mediated activation of PI3K increases the phosphatidylinositol 3,4,5 phosphate ( $\mathrm{PIP}_{3}$ ) levels, leading to Akt activation [15]. The lipid phosphatase PTEN acts as a negative regulator of the PI3K/Akt pathway by dephosphorylating $\mathrm{PIP}_{3}$. Phosphorylated PTEN is unable to associate with the membrane due to a conformational change and, hence, does not inhibit PI3K signaling [16]. The balance between PTEN and PI3K signaling modulates the basal PIP $_{3}$ levels in the plasma membrane, which, in turn, regulates cell survival and proliferation [16].

Lysosomes and cathepsins play a major role in tumor cell death $[17,18]$. The lysosome permeabilization or rupture, facilitates cathepsin release, causing cell death via mitochondria-dependent apoptosis [19,20]. Among lysosomal enzymes, cathepsin B (CB) is a cysteine protease primarily involved in the degradation or processing of lysosomal proteins [21], as well as vesicle trafficking [22], inflammasome generation [23] and cell death [24].

In the present study, we found that sorafenib induces apoptosis of BC cells via the activation and inactivation of PTEN and Akt pathways, respectively, thereby stimulating CB activity and Bid fragmentation, which induced the mitochondrial-dependent pathway of apoptosis. In addition, in the view to reduce the sorafenib-mediated side effects and to maintain the efficiency of drug treatment, our findings provided a rationale for the use of the Akt inhibitor perifosine as an adjuvant with sorafenib in clinical trials of advanced BC.

\section{RESULTS}

\section{Sorafenib inhibits the survival and induces apoptosis in $\mathrm{BC}$ cells}

The ability of sorafenib to inhibit the viability of the 5637 and T24 BC cell lines was evaluated through doseresponse $(2.5,10$ and $20 \mu \mathrm{M})$ (Fig. 1A) and time-course (24, 48 and 72 h) (Fig. 1B) analysis. Sorafenib inhibited the growth of $\mathrm{BC}$ cells at $24 \mathrm{~h}$ after treatment, with $\mathrm{IC}_{50}$ values of $11.57 \mu \mathrm{M}$ and $11.58 \mu \mathrm{M}$ for 5637 and T24 BC cells, respectively.

Then we investigated by FITC-conjugated Annexin $\mathrm{V}$ (Ann V-FITC/PI) staining and flow cytometric analysis, the ability of sorafenib to induce apoptosis of BC. We found that sorafenib at $10 \mu \mathrm{M}$ and $20 \mu \mathrm{M}$ (Supplementary Figure 1) induces dose-dependent apoptosis of both 5637 and T24 BC cells, with $20 \mu \mathrm{M}$ showing higher apoptotic effects compared with dose $10 \mu \mathrm{M}$; the $20 \mu \mathrm{M}$ sorafenibinduced effect started at $12 \mathrm{~h}$ (\% apoptotic cells: $52 \%$ and $62 \%$ in 5637 and T24 BC cells, respectively) and was maximal at $24 \mathrm{~h}$ after treatment (\% apoptotic cells: $60 \%$ and $78 \%$ in 5637 and T24 BC cells, respectively) (Fig. 1C and supplementary Fig S1).

\section{Sorafenib induces lysosome permeabilization, cathepsin $B(C B)$ release and activation in $B C$ cells}

Several studies have suggested a close association between lysosomal function and apoptosis [25]. Moreover, $\mathrm{CB}$ has been demonstrated to be one of the major lysosomal cysteine proteases that plays an important role in apoptosis [26]. Thus, the integrity of lysosome in BC cells, treated with sorafenib, was evaluated by Lysotracker Green staining and cytofluorimetric analysis. Lysotracker was added to $\mathrm{BC}$ cells treated for 1 and $2 \mathrm{~h}$ with sorafenib, and green fluorescence was investigated using the FL1 channel. We found that, due to loss of lysosome integrity, sorafenib mainly reduces the green fluorescence at $1 \mathrm{~h}$ after treatment of about $50 \%$ and $30 \%$ in T24 and 5637 $\mathrm{BC}$ cells, respectively (Fig. 2A). Then, to further address the release of lysosomal CB into the cytosol of BC cells, a cytosolic extract from $\mathrm{BC}$ cells treated for different times ( 1,3 and $6 \mathrm{~h})$ with sorafenib, obtained eliminating cytosolic organelles by ultracentrifugation, was analyzed by immunoblotting. We observed that in sorafenib-treated $\mathrm{BC}$ cells, the $\mathrm{CB}$ level increases in a time-dependent 
manner; it starts at $1 \mathrm{~h}$ and is maximal at $6 \mathrm{~h}$ after treatment (Fig 2B).

In addition, we investigated, by using whole cell lysates, the ability of sorafenib to trigger $\mathrm{CB}$ activation and enzymatic activity in $\mathrm{BC}$ cells. We found that sorafenib treatment increases $\mathrm{CB}$ activation at $1 \mathrm{~h}$ after treatment by stimulating the cleavage of the immature CB pro-peptide (p37) to generate its active form (p25) (Fig. 2C). Moreover, by the use of the fluorogenic peptide Z-Arg-Arg-AMC we also found that sorafenib enhances $\mathrm{CB}$ activity in a time-dependent manner; $\mathrm{CB}$ activity was evidenced at $1 \mathrm{~h}$ and peaks at $6 \mathrm{~h}$ after treatment (Fig. 2D). Overall, these results evidenced that sorafenib induces lysosome leakage, $\mathrm{CB}$ release, activation and enzymatic activity in BC cells.

\section{CB directly interacts with sorafenib}

We demonstrated the feasibility of a molecular interaction between $\mathrm{CB}$ and sorafenib and by performing molecular modeling of the docking site of the potential $\mathrm{CB} /$ sorafenib complex. The analysis of molecular docking between $\mathrm{CB}$ and sorafenib revealed complete insertion of this drug into the catalytic groove of $\mathrm{CB}$, covering the active site (Cys29, His199 and Asn219). In particular, sorafenib bound to CB with a strong affinity $(0.54 \mathrm{nM})$, forming a complex displaying a total intermolecular energy of $-95.35 \mathrm{kcal} / \mathrm{mol}\left(\mathrm{E}_{\mathrm{VdW}}=-77.87 \mathrm{kcal} / \mathrm{mol}\right.$; $\mathrm{E}_{\text {Elect }}$ $=-17.48 \mathrm{kcal} / \mathrm{mol}$ ) (Fig. $3 \mathrm{~A}, \mathrm{~B})$. Notably, this predicted affinity is equivalent to that of the physiological inhibitor cystatin C (0.6nM) [27]. Specifically, the CB/sorafenib complex contained $6 \mathrm{H}$-bonds established via the amino acids His111, Cys119, Glu122, Gly198 and Trp221 (mean length of $2.23 \AA$ ) that contribute to complex stabilization, along with electrostatic and van der Waals forces. As for the interaction between CB and other TKIs [28], CB binds to pazopanib with an affinity of $13.49 \mathrm{nM}$, thus forming a complex displaying a total intermolecular energy of -85.20 $\mathrm{kcal} / \mathrm{mol}\left(\mathrm{E}_{\mathrm{VdW}}=-79.14 \mathrm{kcal} / \mathrm{mol} ; \mathrm{E}_{\text {Elect }}=-6.06 \mathrm{kcal} / \mathrm{mol}\right)$ (Supplementary Fig. 2 A, B). Collectively, the results of
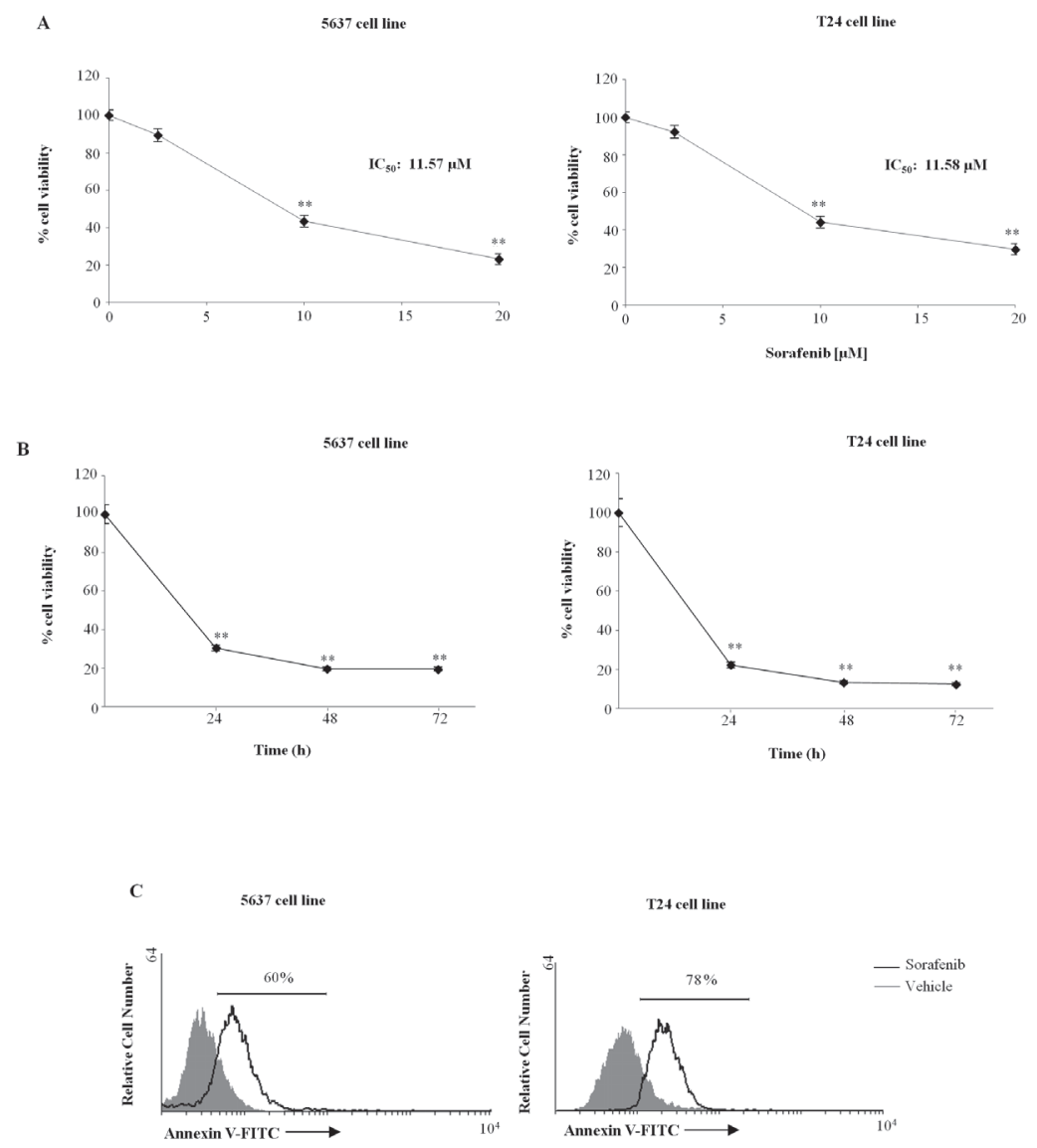

Figure 1: Sorafenib reduces the 5637 and T24 cell viability and induces apoptotic cell death. A) Cell growth was evaluated by MTT assay in 5637 and T24 cells treated with different doses of sorafenib $(2.5,10,20 \mu \mathrm{M})$ for $24 \mathrm{~h}$. Data shown are the mean \pm SD of three independent experiments. ${ }^{*} \mathrm{p}<0.01$, sorafenib- vs vehicle-treated cells. $\mathrm{IC}_{50}$ value was determined as concentration exerting a halfmaximal inhibition of cell growth. B) Cell growth was evaluated by MTT assay in 5637 and BC T24 cells treated with sorafenib (20 $\mu$ M) for different times (24, 48 and $72 \mathrm{~h}$ ). Data shown are the mean \pm SD of three independent experiments. $* * p<0.01$, vs vehicle-treated cells. C) 5637 and T24 cells treated with sorafenib $20 \mu \mathrm{M}$ or with vehicle for $24 \mathrm{~h}$ were stained with Ann V-FITC and analyzed by FACS. One representative experiment out of three independent experiments is shown. 

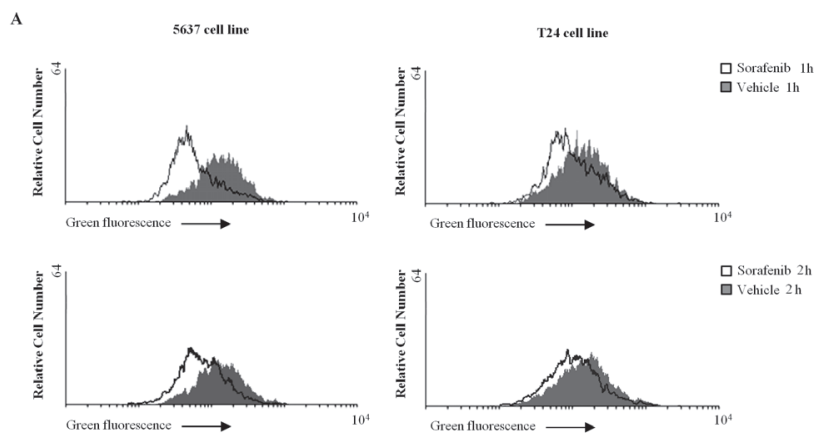

B
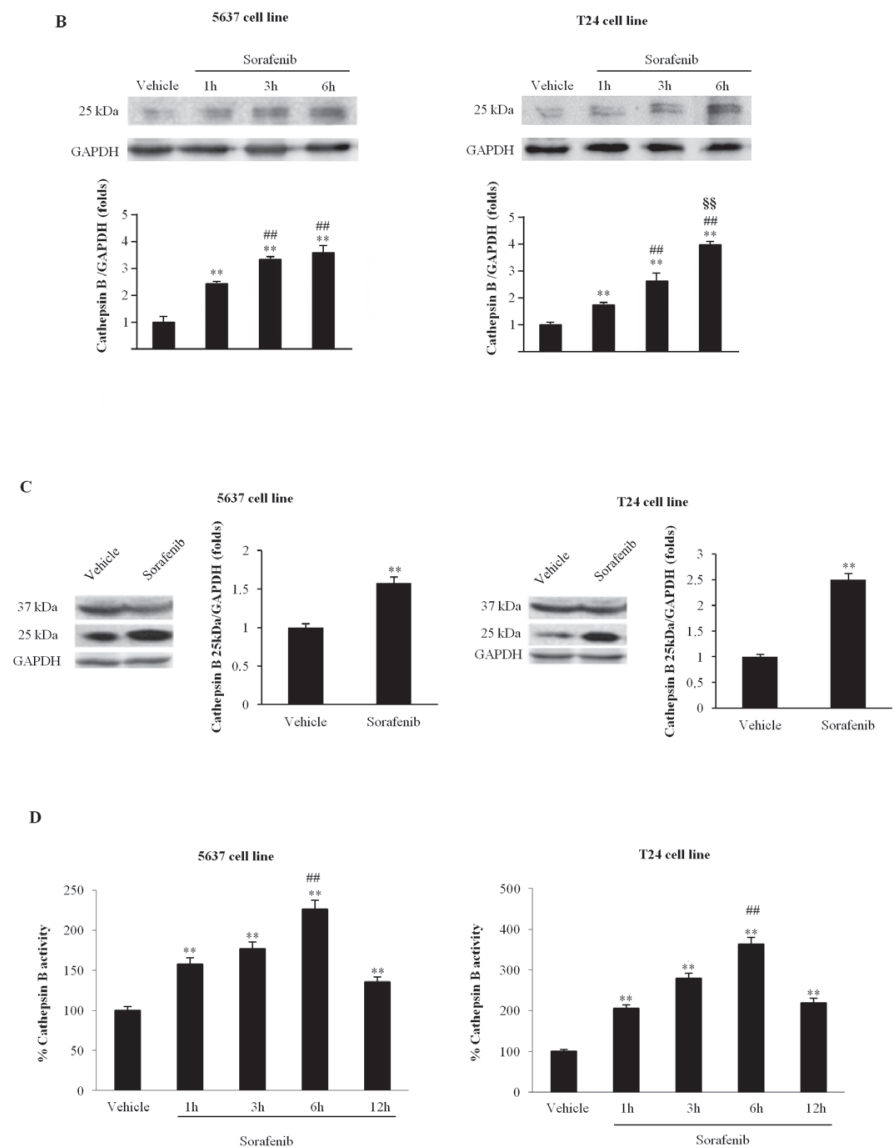

Figure 2: Sorafenib induces lysosome permeabilization and CB activation. A) Lysosome leakage was evaluated in BC cells treated with sorafenib $(20 \mu \mathrm{M})$ or vehicle for 1 and $2 \mathrm{~h}$ by lysotracker staining. One representative experiment out of three independent experiments is shown. B) Representative blots of cytosol extracts from BC cells treated with sorafenib $(20 \mu \mathrm{M})$ for different times or with vehicle for $1 \mathrm{~h}$ probed using an anti-CB Ab. The GAPDH expression levels were used as a loading control. The densitometric data are expressed as the mean $\pm \mathrm{SD}$ of three independent experiments. ${ }^{* *} \mathrm{p}<0.01$ vs vehicle-treated cells; ${ }^{\#} \mathrm{p}<0.01 \mathrm{vs} 1 \mathrm{~h}$ of treatment; ${ }^{\S} \mathrm{p}<0.01 \mathrm{vs}$ $3 \mathrm{~h}$ of treatment. No statistical significant difference was found between untreated and vehicle-treated cells or comparing different times of vehicle-treatment each other (data not shown). C) Lysates from 5637 and T24 cells treated for $1 \mathrm{~h}$ with sorafenib (20 $\mu \mathrm{M})$ or vehicle were separated via $12 \%$ SDS-PAGE and probed using an anti-CB Ab. The GAPDH expression levels were used as a loading control. One representative experiment is shown. The densitometric data are expressed as the mean $\pm \mathrm{SD}$ of three independent experiments. $* * p<0.01$ vs vehicle-treated cells. No statistical significant difference was found between untreated and vehicle-treated cells (data not shown). D) $\mathrm{CB}$ activity was measured in 5637 and T24 cells treated for different periods with sorafenib $(20 \mu \mathrm{M})$ or for $1 \mathrm{~h}$ with vehicle using the fluorogenic peptide Z-Arg-Arg-AMC and a SpectraMax Gemini XPS microplate reader. The presented data are expressed as the means $\pm \mathrm{SD}$ of three independent experiments. ${ }^{*} \mathrm{p}<0.01$ vs vehicle-treated cells; ${ }^{* \#} \mathrm{p}<0.01$ vs 1,3 or $12 \mathrm{~h}$ of treatment. No statistical significant difference was found between untreated and vehicle-treated cells or comparing different times of vehicle-treatment each other (data not shown). 
molecular modeling and the comparative analysis with pazopanib strongly suggest that there is a direct interaction between $\mathrm{CB}$ and sorafenib that forms a stable complex.

\section{Sorafenib, through CB activation, induces Bid activation that triggers the intrinsic pathway of apoptosis in $\mathrm{BC}$ cells}

$\mathrm{CB}$ has been found to activate the conversion of Bid to its active form tBid and consequently to trigger the intrinsic pathway of apoptosis [29]. Thus, the effect of sorafenib on Bid activation was evaluated. We found that treatment with sorafenib $(20 \mu \mathrm{M})$ for 6 and $12 \mathrm{~h}$ induces the cleavage of the pro-apoptotic Bid protein to generate the truncated form tBid, resulting in a reduction in Bid (p22) expression and a parallel increase in tBid (p15) expression (Fig. 4A). This effect was markedly reverted at $6 \mathrm{~h}$ after sorafenib treatment by the $\mathrm{CB}$ inhibitor, CA074Me used at $2.5 \mu \mathrm{M}$ (Fig. 4B) and $5 \mu \mathrm{M}$ (data not shown). Next, the involvement of mitochondria and ROS generation in the sorafenib-induced apoptosis of $\mathrm{BC}$ cells was evaluated via JC-1 and DCFDA staining and FACS analysis. We found that sorafenib induces a timedependent decrease in $\Delta \Psi \mathrm{m}$ and a parallel increase in ROS production in both types of BC cells. Mitochondrial depolarization was detected approximately at $8 \mathrm{~h}$ and peaking at $24 \mathrm{~h}$ after treatment $(89.8 \%$ in 5637 cells; $82.6 \%$ in T24 BC cells) (Fig. 4C). We also observed that sorafenib stimulates ROS generation that peaks at $8 \mathrm{~h}$ and declines at the later time point (Fig. 4D). In addition, by western blot analysis of sorafenib-treated cytosol extracts of $\mathrm{BC}$ cells, we found that sorafenib induces

A

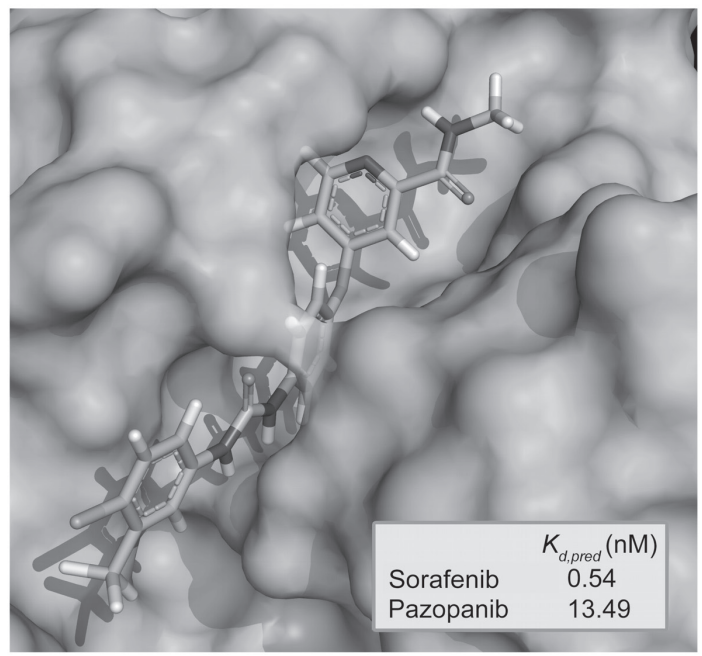

the translocation of cytochrome $\mathrm{c}$ from the mitochondria to the cytosol of BC cells (Fig. 4E). Finally, we further examined the caspase-dependence of sorafenib-induced apoptosis. Thus, the BC cells were treated for $12 \mathrm{~h}$ with $10 \mu \mathrm{M}$ (Fig. 4E) and $50 \mu \mathrm{M}$ (data not shown) of the pancaspase inhibitor, the ZVAD-fmk peptide alone or in combination with sorafenib. A significant reduction in the percentage of apoptotic Ann $\mathrm{V}^{+}$cells was detected in BC cells treated with sorafenib $(20 \mu \mathrm{M})$ and ZVAD-fmk (10, $50 \mu \mathrm{M})$ compared with those cells treated with sorafenib alone (Fig. 4F).

Collectively, these results indicate that, sorafenib, activating $\mathrm{CB}$, stimulates BID cleavage and promotes the activation of the mitochondrial-dependent intrinsic pathway of apoptosis in $\mathrm{BC}$ cells.

\section{Role of PTEN in sorafenib-induced CB activation in $\mathrm{BC}$ cells}

Sorafenib has been shown to activate various PTPs in different cell types [14,30-32]. Herein, the effect of sorafenib on SHP-1 and/or PTEN activation was evaluated in $\mathrm{BC}$ cells via western blot analysis. We found that although SHP-1 is expressed in T24 BC cells, sorafenib does not induce SHP-1 phosphorylation at any time point after sorafenib treatment (Supplementary Fig. 3). In addition, sorafenib significantly increased PTEN phosphatase activity in a time-dependent manner, as shown by the increase in the non-phosphorylated PTEN levels in T24 cells. PTEN dephosphorylation was initially detected at $15 \mathrm{~min}$, progressively increasing until $1 \mathrm{~h}$ and slightly decreasing at $2 \mathrm{~h}$ after sorafenib treatment (Fig.

B

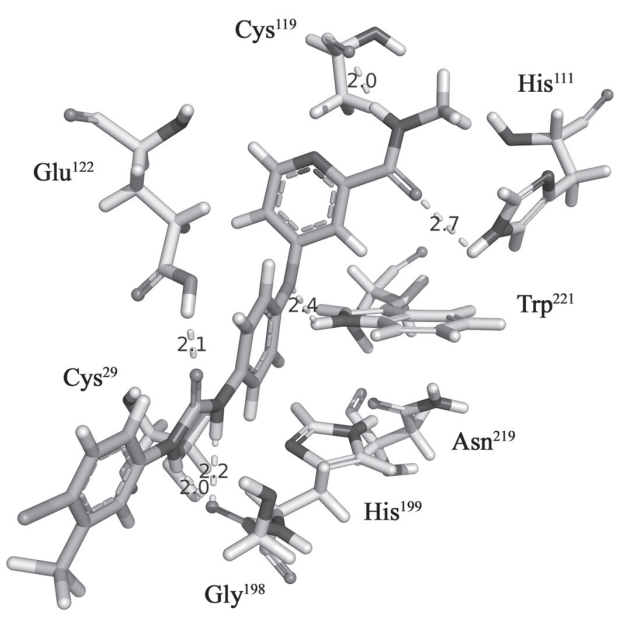

Figure 3: The catalytic groove of CB interacts with sorafenib. A) Sorafenib docks in the catalytic groove of CB (represented with protein surface) and covers the active site. The predicted equilibrium dissociation constant $\left(\mathrm{K}_{\mathrm{d}^{\prime} \text { pred }}\right)$ of the sorafenib/CB complex compared with that of pazopanib/CB is shown in the box. B) Cys29 and the other amino acids of CB involved in H-bond formation with the drug are indicated. 
A

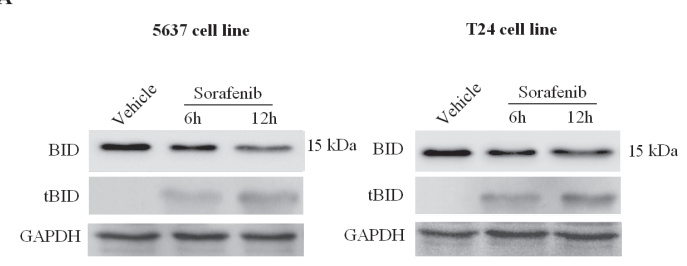

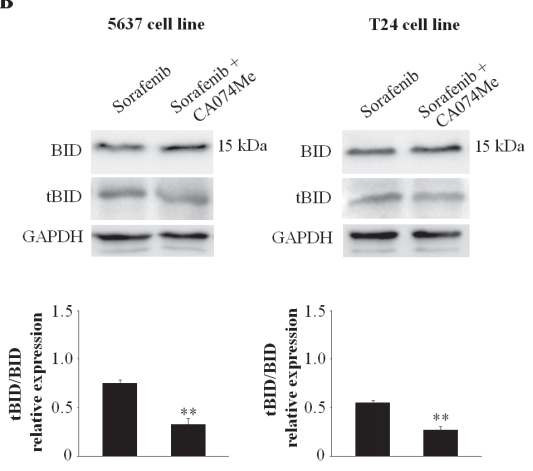

D

C
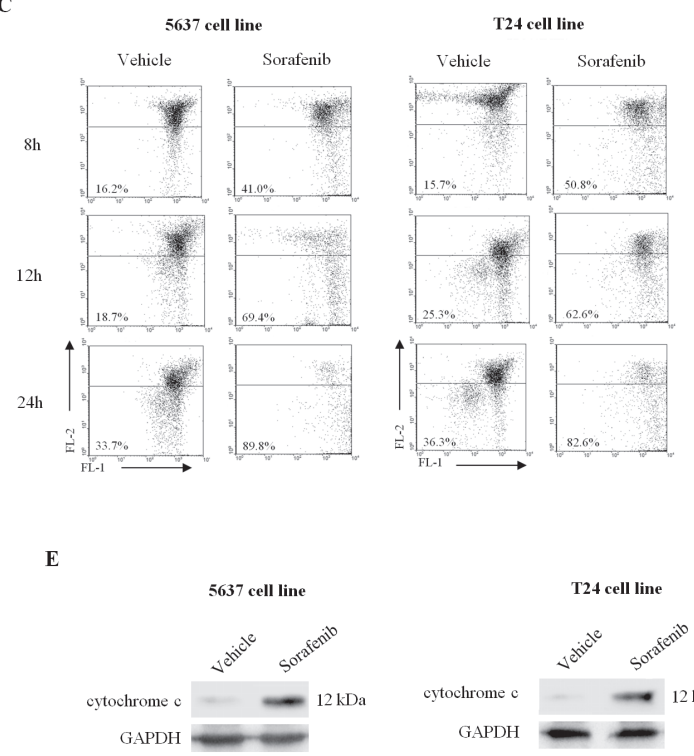
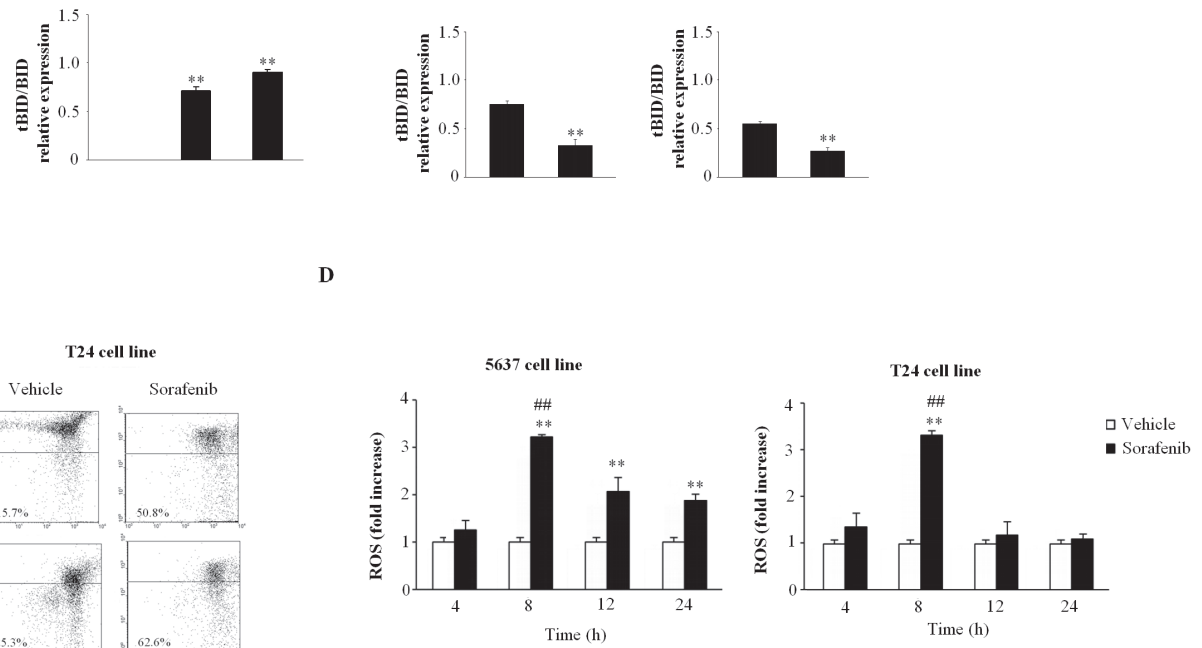

F
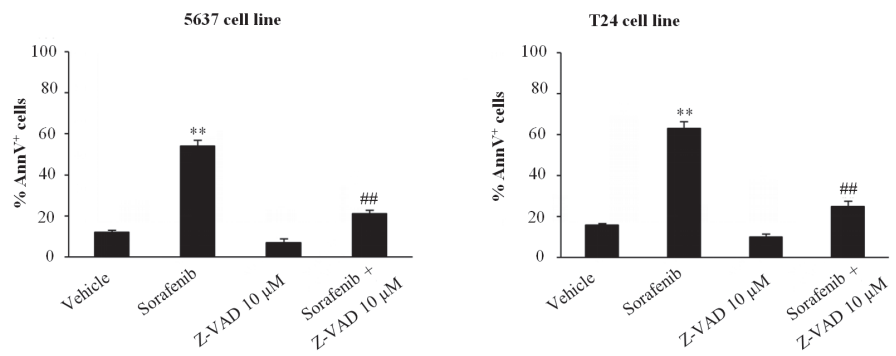

Figure 4: Sorafenib induces BID cleavage and mitochondrial-dependent apoptosis in 5637 and T24 BC cells. A) Lysates from 5637 and T24 cells treated for 6 or $12 \mathrm{~h}$ with sorafenib $(20 \mu \mathrm{M})$ or for $6 \mathrm{~h}$ with vehicle were separated via $12 \%$ SDS-PAGE and probed using an anti-Bid or anti-GAPDH Abs. One representative experiment out of three independent experiments is shown. The densitometric data are expressed as the mean $\pm \mathrm{SD}$ of three independent experiments. ${ }^{*} \mathrm{p} p<0.01$ vs vehicle-treated cells; ${ }^{* \#} \mathrm{p}<0.01$ vs $6 \mathrm{~h}$ of treatment. No statistical significant difference was found between untreated and vehicle-treated cells or comparing different times of vehicle-treatment each other (data not shown). B) Lysates from 5637 and T24 cells treated for $6 \mathrm{~h}$ with sorafenib $(20 \mu \mathrm{M})$ alone or in combination with CA074Me were separated via 12\% SDS-PAGE and probed using an anti-Bid or anti-GAPDH Abs. One representative experiment is shown. The densitometric data are expressed as the mean $\pm \mathrm{SD}$ of three independent experiments. $* * \mathrm{p}<0.01 \mathrm{vs}$ sorafenib-treated cells. C) $\Delta \Psi \mathrm{m}$ changes on 5637 and T24 BC cells, treated with sorafenib $(20 \mu \mathrm{M})$ or vehicle, was evaluated at different times by JC-1 staining and biparametric FL1(green)/FL2(red) flow cytometric analysis. Data represent one out of three separate experiments. Numbers are the percentage of cells showing a drop of $\Delta \Psi \mathrm{m}$ related fluorescence intensity. D) ROS production was evaluated in 5637 and T24 BC cells treated for different periods with sorafenib $(20 \mu \mathrm{M})$ or vehicle via DCFDA staining and FACS analysis. The data are presented as the mean $\pm \mathrm{SD}$ of three independent experiments and are expressed as the fold-change relative to the vehicle-treated cell. ${ }^{* *} \mathrm{p}<0.01 \mathrm{vs}$ vehicle-treated cells; $\#$ p $<0.01$ vs 4,12 or $24 \mathrm{~h}$ of treatment. E) Cytosolic extracts from 5637 and T24 BC cells treated for $6 \mathrm{~h}$ with sorafenib (20 $\mu \mathrm{M})$ or vehicle were separated via 12\% SDS-PAGE and probed using an anti-cytochrome c Ab. The GAPDH expression levels were used as a loading control. One representative experiment out of three independent experiments is shown. F) 5637 and T24 BC cells treated for $12 \mathrm{~h}$ with sorafenib $(20 \mu \mathrm{M})$ alone or in combination with $(10 \mu \mathrm{M})$ Z-VAD-FMK were stained with Ann V-FITC and analyzed via FACS. The data are expressed as the percentages of positive cells \pm SD based on three separate experiments. ${ }^{* *} \mathrm{p}<0.01$ vs vehicle-treated cells; ${ }^{\# \#} \mathrm{p}<0.01$ vs sorafenib-treated cells. 
5A). No changes in the total PTEN protein levels were detected in the sorafenib-treated T24 BC cells. Similar results were obtained using $5637 \mathrm{BC}$ cells (data not shown). Pretreatment of BC cells with $0.25 \mathrm{mM}$ (Fig. 5B) and $0.50 \mathrm{mM}$ (data not shown) of the specific tyrosinephosphatase inhibitor, orthovanadate for $30 \mathrm{~min}$ prior to treatment with sorafenib $(20 \mu \mathrm{M})$ strongly reduced at $12 \mathrm{~h}$ after treatment, the percentage of sorafenib-induced Ann $\mathrm{V}^{+}$apoptotic cells, as evaluated by FACS analysis (Fig. 5B).

Recent report showed that the increase of $\mathrm{CB}$ activity is related to its rapid tyrosine-dephosphorylation [33]. Thus, the ability of sorafenib to reduce CB tyrosine phosphorylation levels was evaluated. Based on immunoprecipitation and western blot analyses using anti-pTyr and anti-CB Abs, we demonstrated that in BC cells, CB is tyrosine phosphorylated at a basal level and that treatment with sorafenib decreases the $\mathrm{CB}$ tyrosine phosphorylation levels in a time-dependent manner (\% of decrease: $60 \%$ and $75 \%$ at $1 \mathrm{~h}$ and $3 \mathrm{~h}$, respectively) (Fig. 5C). Moreover, pretreatment of sorafenib-treated BC cells with orthovanadate markedly reduced CB activity in a time-dependent manner (Fig. 5D). Similar results were obtained using $5637 \mathrm{BC}$ cells (data not shown). Taken together, these data indicate that sorafenib increases $\mathrm{CB}$ activity by inducing $\mathrm{CB}$ tyrosine dephosphorylation and this effect is likely mediated by PTEN activation.

\section{Sorafenib suppresses Akt tyrosine kinase activity by promoting Akt degradation in $\mathrm{BC}$ cells}

PTEN is a negative regulator of Akt activity [16] and sorafenib has been found to induce PTEN activation.
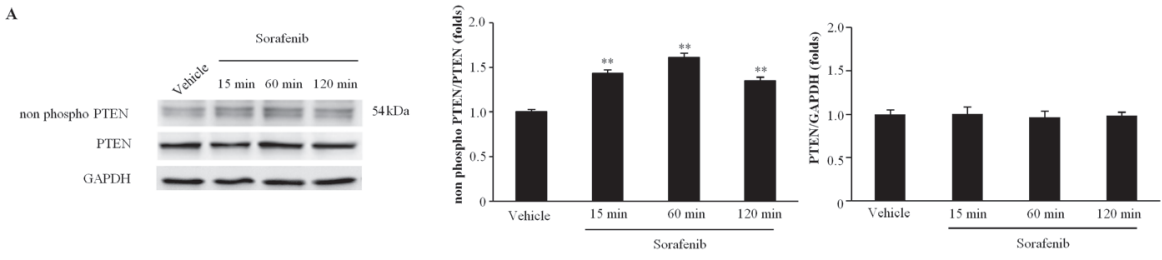

B

5637 cell line
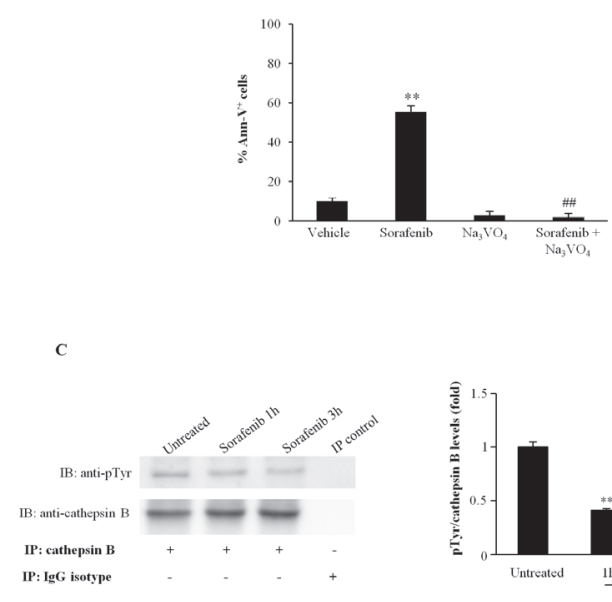
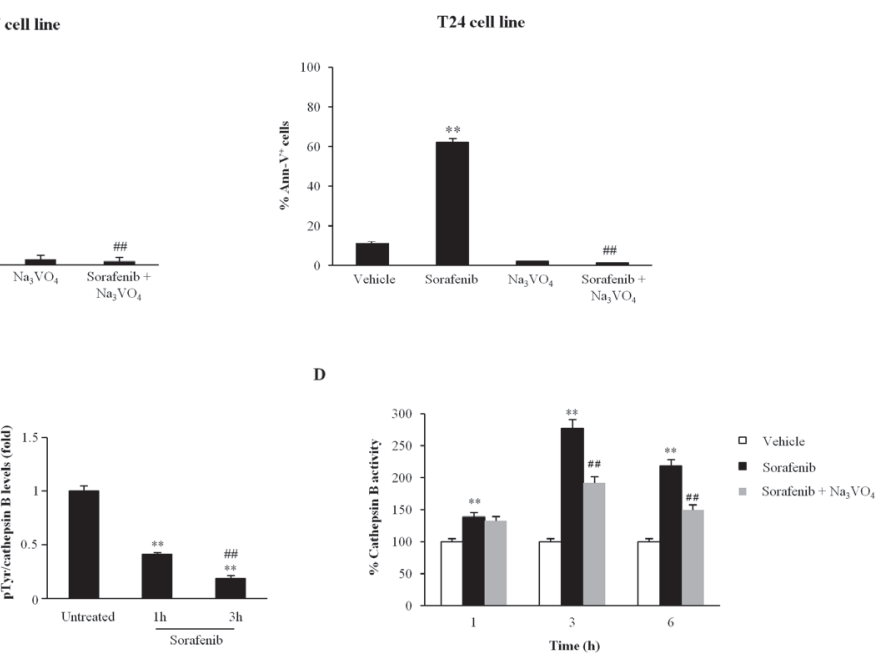

Figure 5: Sorafenib stimulates CB dephosphorylation and PTEN activity in T24 BC cells. A) Lysates from T24 cells treated with sorafenib $(20 \mu \mathrm{M})$ for 15,60 and 120 min or with vehicle for 15 min were separated via $9 \%$ SDS-PAGE and probed using anti-non-phospho-PTEN, anti-PTEN and anti-GAPDH Abs. One representative experiment is shown. The densitometric data are expressed as the mean $\pm \mathrm{SD}$ of three separate experiments. ${ }^{*} \mathrm{p}<0.01$ vs vehicle-treated cells. No statistical significant difference was found between untreated and vehicle-treated cells or comparing different times of vehicle-treatment each other (data not shown). B) T24 BC cells treated for $12 \mathrm{~h}$ with sorafenib $(20 \mu \mathrm{M})$, alone or in combination with orthovanadate $\left(\mathrm{Na}_{3} \mathrm{VO}_{4}, 0.25 \mathrm{mM}\right)$ were stained with Ann V-FITC and analyzed via FACS. The data are expressed as the percentage of positive cells and are presented as the means $\pm \mathrm{SD}$ of three independent experiments. ${ }^{* *} \mathrm{p}<0.01$ vs vehicle-treated cells; ${ }^{\#} \mathrm{p}<0.01$ vs sorafenib-treated cells. C) Cell lysates from T24 BC cells either untreated or treated with sorafenib $(20 \mu \mathrm{M})$ for 1 or $3 \mathrm{~h}$ were immunoprecipitated (IP) using a monoclonal anti-CB Ab. The immunoprecipitates were separated via $12 \%$ SDS-PAGE and then immunoblotted (IB) using Abs against phospho-tyrosine (anti-pTyr) and CB. The lysates were also immunoprecipitated using isotype-matched IgG, which was used as a control. One representative experiment is shown. The densitometric data are expressed as the mean $\pm \mathrm{SD}$ of three separate experiments. $* * \mathrm{p}<0.01$ vs untreated cells; ${ }^{*} \mathrm{p} p<0.01$ vs $1 \mathrm{~h}$ of treatment. D) CB activity was measured in T24 BC cells treated for different periods with vehicle or sorafenib $(20 \mu \mathrm{M})$ either alone or in combination with orthovanadate $\left(\mathrm{Na}_{3} \mathrm{VO}_{4}, 0.25 \mathrm{mM}\right)$. The data are presented as the means $\pm \mathrm{SD}$ of three independent experiments. $* * \mathrm{p}<0.01$ vs vehicletreated cells; ${ }^{\#} \mathrm{p}<0.01$ vs sorafenib-treated cells. Data shown are relative to T24 cell line and are representative of BC lines analyzed. 
Thus, the ability of sorafenib to reduce the Akt tyrosine phosphorylation levels in T24 BC cells was evaluated. Based on western blot analysis, we demonstrated that sorafenib inhibits Akt phosphorylation in T24 BC cells in a time-dependent manner (Fig. 6A). The inhibition of phosphor-Akt expression paralleled that of the total Akt protein, indicating that in T24 BC cells, sorafenib acts inducing a time-dependent down-regulation of the Akt protein (Fig. 6A). Then, we further examined the ability of perifosine, a specific inhibitor of Akt phosphorylation, to inhibit CB tyrosine phosphorylation in T24 BC cells. We showed that at $3 \mathrm{~h}$ after treatment, perifosine markedly reduces the basal $\mathrm{CB}$ tyrosine phosphorylation levels in a dose-dependent manner (Fig. 6B). Similar results were obtained using 5637 BC cells (data not shown). Finally, to elucidate the mechanism of Akt down-regulation, $\mathrm{BC}$ cells were treated for $6 \mathrm{~h}$ with sorafenib in the presence of $50 \mathrm{nM}$ (Fig. 6C) and $100 \mathrm{nM}$ (data not shown) of the lysosome inhibitor, bafylomycin A (Fig. 6C). We found that bafylomycin A completely blocks sorafenib-induced
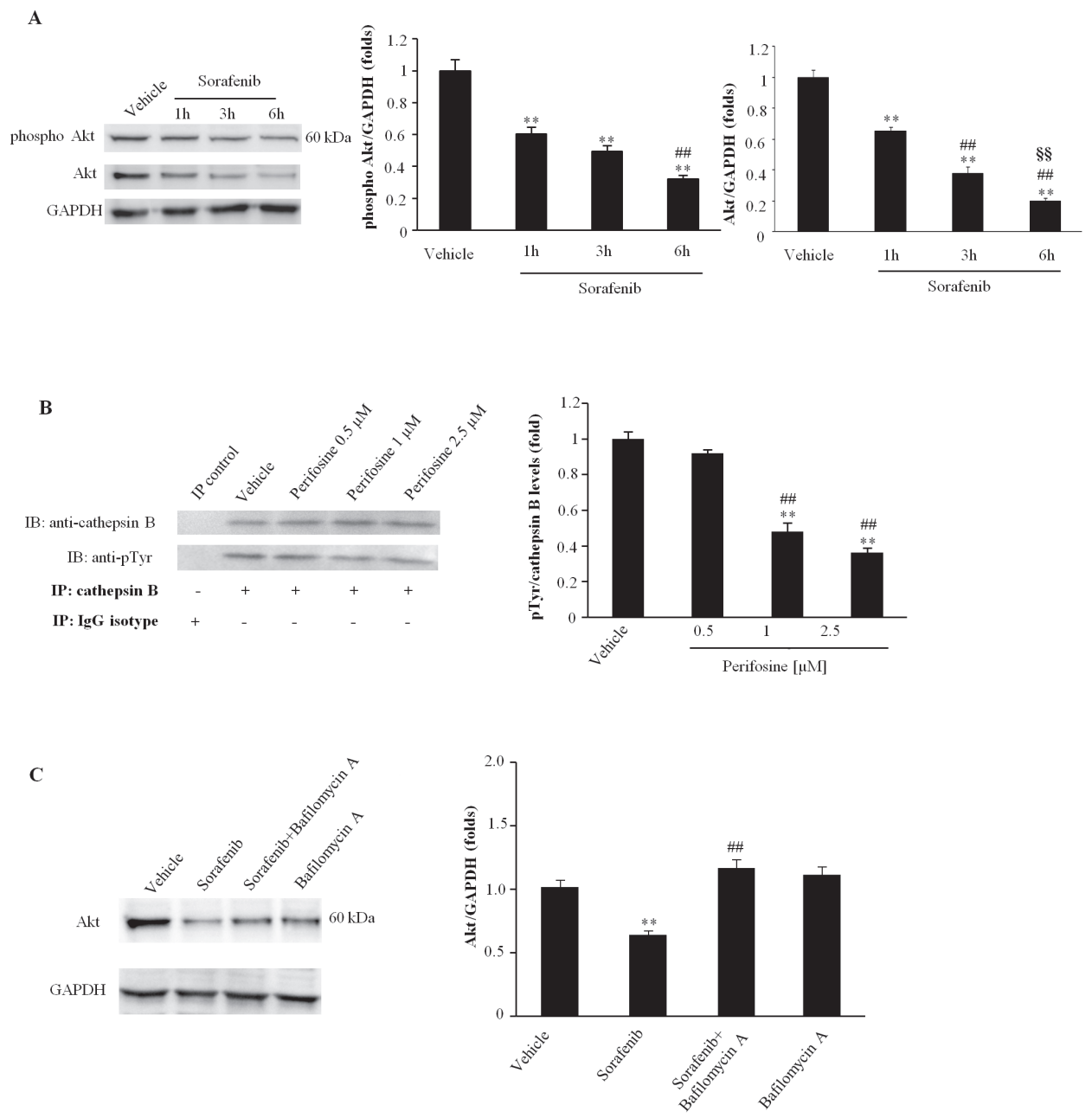

Figure 6: Sorafenib induces degradation of the Akt protein in T24 BC cells. A) In the representative immunoblots lysates from T24 cells treated with sorafenib $(20 \mu \mathrm{M})$ for different times or with vehicle for $1 \mathrm{~h}$ were probed using anti-phospho-Akt, anti-Akt and anti-GAPDH Abs. The densitometric data are expressed as the mean \pm SD of three separate experiments. ${ }^{* *} \mathrm{p}<0.01$ vs vehicle-treated cells; ${ }^{\#} \mathrm{p}<0.01$ vs $1 \mathrm{~h}$ of treatment; ${ }^{\S} \mathrm{p}<0.01$ vs $3 \mathrm{~h}$ of treatment. No statistical significant difference was found between untreated and vehicletreated cells or comparing different times of vehicle-treatment each other (data not shown). B) Cell lysates from T24 cells treated for $3 \mathrm{~h}$ with vehicle or perifosine $(0.5,1$ or $2.5 \mu \mathrm{M})$ were immunoprecipitated (IP) using a monoclonal anti-CB Ab. The immunoprecipitates were separated via $12 \%$ SDS-PAGE and then immunoblotted (IB) using Abs against phospho-tyrosine (pTyr) and CB. The lysates were also immunoprecipitated using isotype-matched $\mathrm{IgG}$, which was used as a control. One representative experiment is shown. The densitometric data are expressed as the mean $\pm \mathrm{SD}$ of three separate experiments. ${ }^{*} \mathrm{p} p<0.01$ vs vehicle-treated cells; ${ }^{\# \#} \mathrm{p}<0.01$ vs $0.5 \mu \mathrm{M}$ of perifosine. No statistical significant difference was found between untreated and vehicle-treated cells (data not shown). C) Lysates from T24 cells treated for $6 \mathrm{~h}$ with vehicle or sorafenib $(20 \mu \mathrm{M})$ and bafilomycin A1 $(50 \mathrm{nM})$ alone or in combination were separated via 9\% SDS-PAGE and probed using anti-Akt or anti-GAPDH Abs. One representative experiment is shown. The densitometric data are expressed as the mean \pm $\mathrm{SD}$ of three separate experiments. ${ }^{* *} \mathrm{p}<0.01$ vs vehicle-treated cells; ${ }^{*} \mathrm{p}<0.01$ vs sorafenib-treated cells. No statistical significant difference was found between untreated and vehicle-treated cells or comparing different vehicles-treatment each other (data not shown). Data shown are relative to $\mathrm{T} 24$ cell line and are representative of $\mathrm{BC}$ lines analyzed. 
Akt protein degradation. Treatment with the lysosome inhibitor in the absence of sorafenib did not induce any significant effect (Fig. 6C). Similar results were obtained using the $5637 \mathrm{BC}$ cells (data not shown).

\section{The Akt inhibitor perifosine sensitizes BC cells to sorafenib-induced apoptotic cell death}

Recent data have indicated that sorafenib in combination with perifosine induces mitochondriamediated cell death and anti-tumor effects in NOD/SCID mice xenografted with a Hodgkin lymphoma cell line [34]. However, neither in vitro nor in vivo findings on the effects of sorafenib administered in combination with perifosine has been reported in $\mathrm{BC}$ cells to date. Thus, we evaluated the effects of different doses of perifosine $(0.5,1.0$ or 2.5 $\mu \mathrm{M})$ alone and in combination with sorafenib (10 and 20 $\mu \mathrm{M})$ in $\mathrm{T} 24 \mathrm{BC}$ cells. We found that perifosine reduces the viability of $\mathrm{T} 24 \mathrm{BC}$ cells in a dose-dependent manner at $24 \mathrm{~h}$, showing a maximal effect (42.1\% of inhibition) with the $2.5 \mu \mathrm{M}$ dose (Fig. 7A). By standard isobologram and CompuSyn software analysis we evaluated the combination index $(\mathrm{CI})$ and we found that the combination of sorafenib 10 or $20 \mu \mathrm{M}$ with perifosine at the doses 1 and $2.5 \mu \mathrm{M}$ shows synergistic effect increasing the cytotoxicity against T24 BC cells (Fig. 7B). Moreover, the use of sorafenib at $10 \mu \mathrm{M}$ in combination with perifosine at different doses $(1.0$ or $2.5 \mu \mathrm{M})$ approximates the cytotoxic effects induced by sorafenib $(20 \mu \mathrm{M})$ alone (Fig. 7B). This synergistic effect does not depend on the direct ability of perifosine to induce apoptosis (Fig. 7C), although, the perifosine/sorafenib combination significantly increases the sorafenib-induced apoptosis of BC cells (Fig. 7C). Thus, perifosine by inducing $\mathrm{CB}$ activation sensitized the

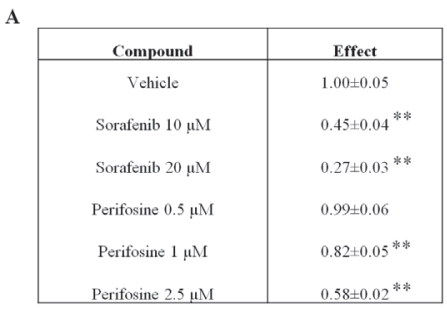

B

\begin{tabular}{|c|c|c|c|}
\hline Sorafenib $(\mu M)$ & Perifosine $(\mu \mathbf{M})$ & Effect & C \\
\hline 10.0 & 0.5 & 0.43 & 122.459 \\
10.0 & 1.0 & 0.3 & 0.87368 \\
10.0 & 2.5 & 0.22 & 0.99807 \\
20.0 & 0.5 & 0.29 & 125.092 \\
20.0 & 1.0 & 0.15 & 0.67291 \\
20.0 & 2.5 & 0.1 & 0.72153 \\
\hline
\end{tabular}

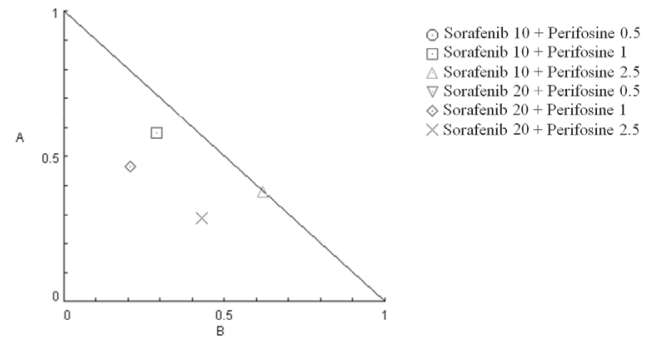

C

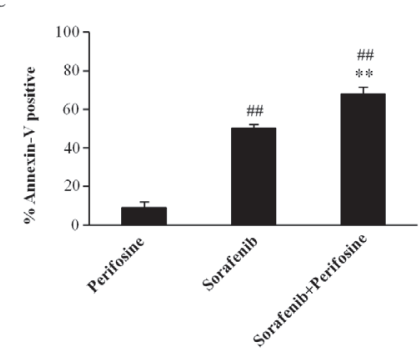

Figure 7: Perifosine in combination with sorafenib increases the sensitivity of T24 BC cells to the sorafenib-induced cytotoxicity. A) Cell viability of $\mathrm{T} 24 \mathrm{BC}$ cells untreated or treated for $24 \mathrm{~h}$ with sorafenib $(10$ and $20 \mu \mathrm{M})$ and perifosine $(0.5,1,2.5$ $\mu \mathrm{M})$ was evaluated by MTT assay. Data shown are the mean \pm SD of three independent experiments. ${ }^{* *} \mathrm{p}<0.01$ vs vehicle-treated cells; No statistical significant difference was found between untreated and vehicles-treated cells (data not shown). For sake of simplicity only one vehicle sample is shown. B) The synergistic activity of sorafenib and perifosine used in combination on the viability of T24 BC cells was determined by the isobologram and combination index $(\mathrm{CI})$ methods. The $\mathrm{CI}$ was used to express synergism $(\mathrm{CI}<1)$, additivity $(\mathrm{CI}=1)$ or antagonism (CI $>1)$ and was calculated according to the standard isobologram equation. C) T24 BC cells treated for $24 \mathrm{~h}$ with sorafenib $(10 \mu \mathrm{M})$ and perifosine $(2.5 \mu \mathrm{M})$ alone or in combination, were stained with Ann V-FITC and analyzed by FACS. Data, expressed as the percentage of Ann V positive cells, are the mean $\pm \mathrm{SD}$ of three separate experiments. ${ }^{* *} \mathrm{p}<0.01 \mathrm{vs}$ sorafenib-treated cells; ${ }^{\#} \mathrm{p}<0.01 \mathrm{vs}$ perifosine-treated cells. Data shown are relative to T24 cell line and are representative of BC lines analyzed. 
$\mathrm{BC}$ cells to sorafenib-induced apoptosis. Similar results were obtained using the $5637 \mathrm{BC}$ cells (data not shown).

\section{DISCUSSION}

Herein, we demonstrated that sorafenib treatment stimulates the intrinsic pathway of apoptosis in BC cells. Several studies have suggested a close association between lysosomal function and apoptosis [25,35-38]. Anti-cancer agents have been reported to induce lysosome membrane permeabilization (LMP) [37,39-41], or rupture [25,42] which is followed by the release of lysosomal cathepsins. It has been shown that lysosomes are particularly sensitive toward oxidative stress $[43,44]$.

Here, we demonstrated, for the first time, that the sorafenib-induced effects are mediated by its ability to stimulate the LMP leading to release of CB into the cytosol of $\mathrm{BC}$ cells. Then, BID activation and release of the tBid fragment [19], mitochondrial depolarization and cytochrome c release, ROS production and caspase activation are induced, resulting in the complete execution of the intrinsic pathway of apoptosis [17,45]. Similarly, in murine (MBT2 and MB49) and human T24 BC cells, Bacillus Calmette-Guerin induces CB activation and Bid fragmentation, thereby activating the intrinsic apoptotic pathway [29]. The effect of sorafenib treatment on $\mathrm{CB}$ activation in $\mathrm{BC}$ cells was further supported by a molecular docking analysis of the molecular interaction between $\mathrm{CB}$ and sorafenib that indicated a complete insertion of sorafenib into the catalytic groove of $\mathrm{CB}$ with a strong binding affinity (25-fold higher than pazopanib). The molecular interaction between $\mathrm{CB}$ and sorafenib results in the formation of a stable complex. In this regard, Cathepsins have been found to form multimolecular molecular complex with different molecules such us signaling and cytoscheleton proteins and drugs, and a role for these complexes in apoptotic cell death have been provided [46]. Thus, we can hypothesize that CB also binds Akt and/or PTEN, other than sorafenib, to form a three molecular complex permitting both PTEN and CB dephosphorylation and activation. In this view, recently, it has been found that the increase in CB activity is associated with its rapid tyrosine dephosphorylation [33]. Structural analysis of CB revealed many phosphorylation sites for protein kinase $\mathrm{C}$ or casein kinase II, as well as a tyrosine kinase phosphorylation site [33]. In this regard, based on immunoprecipitation and western blot analysis using anti-CB and anti-pTyr Abs, respectively, we confirmed not only that $\mathrm{CB}$ is tyrosine phosphorylated at a basal level, but also that sorafenib treatment significantly reduces the $\mathrm{CB}$ phosphorylation levels. Moreover, orthovanadate, that inhibits PTEN activation, reverts the sorafenib-induced apoptosis in BC cells, suggesting that sorafenib-induced $\mathrm{CB}$ tyrosine dephosphorylation represents a requisite to obtain the necessary $\mathrm{CB}$ enzymatic activity required to stimulate apoptosis in
$\mathrm{BC}$ cells. Previous reports have indicated that sorafenib treatment stimulates SHP-1 and/or SHP-2 tyrosine phosphatase activity in breast cancer [32], glioblastoma [30], HCC [14] and pancreatic cancer [31] and that orthovanadate reduces the sorafenib-induced inhibition of signal transducer and activator of transcription 3 (STAT3)mediated tyrosine phosphorylation and increased PTP and SHP-2 activity in glioma cells [30]. Herein, we found that sorafenib significantly induces PTEN dephosphorylation, as evidenced by the increase in the non-phosphorylated form of PTEN relative to the total PTEN levels, and activation of its phosphatase activity [16]. Thus, the sorafenib-induced increase in $\mathrm{CB}$ activity results in Bid activation, thereby stimulating the apoptosis of $\mathrm{BC}$ cells. In addition, the $\mathrm{CB}$ dephosphorylation, might also occur via sorafenib-induced inhibition of Akt tyrosine kinase activity. In this regard, sorafenib reduces the Akt phosphorylation by inducing the degradation of the Akt protein. Pretreatment of $\mathrm{BC}$ cells with the lysosomal enzyme inhibitor bafilomycin A completely abrogated the sorafenib-induced Akt degradation, demonstrating that sorafenib acts at a post-transcriptional level by inducing lysosome-dependent degradation of the Akt protein [47]. Similarly, sorafenib has been demonstrated to promote the lysosomal degradation of RET protein in HEK293 cells [48] and bafilomycin A inhibits the sorafenibinduced degradation of ATP-binding cassette sub-family G member 2 transporters (ABCG2) in ABCG2-transfected HEK293 cells [49]. Collectively, our data demonstrated that sorafenib treatment by inducing PTEN activation and Akt inactivation/degradation, increases the $\mathrm{CB}$ dephosphorylation and enzymatic activity, thus stimulating $\mathrm{BC}$ cell apoptosis.

Perifosine is an oral Akt inhibitor, currently evaluated in phase III clinical trials, shown to inhibit Akt and mitogen-activated protein kinase (MAPK) phosphorylation in prostate PC3 cells, multiple myeloma, HCC, glioma cells and renal carcinoma [50-54]. In addition in lymphoma cells, the perifosine is used in combination with sorafenib [34]. No data on the ability of perifosine to increase sorafenib-mediated cytotoxicity in $\mathrm{BC}$ cells has been reported so far. By isobologram analysis we found that sorafenib $(10 \mu \mathrm{M})$ in combination with perifosine $(2.5 \mu \mathrm{M})$, synergize to increase the cytotoxicity against T24 BC cells. The effect of sorafenib/perifosine drug combination in T24 BC cells, does not depend on the ability of perifosine to directly stimulate the apoptosis, but also to increase the $\mathrm{CB}$ activation by inducing dephosphorylation and activation of $\mathrm{CB}$, thus sensitizing $\mathrm{BC}$ cells to sorafenib-induced apoptosis.

The knowledge of the molecular mechanisms of the direct anti-tumor effect of sorafenib could permit to identify new therapeutic targets to improve the care of advanced bladder cancer patients.

Overall, in this study we demonstrated that activation of PTEN- and the inactivation of Akt-mediated- 
pathways by sorafenib stimulates the CB-dependent apoptosis of BC cells. Finally, the "dual target therapy" with perifosine and low dose of sorafenib in combination, by coupling the effects of sorafenib on PTEN and Akt dephosphorylation, with that induced by perifosine on $\mathrm{CB}$ dephosphorylation and activation, improves the sorafenib anti-tumor effects and potentially reduce the side-effects, thus providing a rationale for the use in clinical trials in patients suffering from advanced BC.

\section{MATERIALS AND METHODS}

\section{BC cell lines}

The p53 mutant, 5637 and T24 BC cell lines, purchased from American Type Culture Collection (ATCC, Rockville, MD, USA), were maintained in RPMI1640 medium (Lonza Bioresearch, Basel, Switzerland) supplemented with $10 \%$ heat-inactivated fetal bovine serum, $2.5 \mathrm{mM} \quad \mathrm{N}$-2-hydroxyethylpiperazine-N'-2ethanesulfonicacid (HEPES), 2mM L-glutamine, $100 \mathrm{IU} /$ $\mathrm{ml}$ of penicillin, $100 \mu \mathrm{g} / \mathrm{ml}$ of streptomycin (Lonza) at $37^{\circ} \mathrm{C}, 5 \% \mathrm{CO}_{2}$ and $95 \%$ humidity.

\section{Reagents}

Sorafenib was kindly provided by Bayer Pharmaceuticals. The following rabbit polyclonal antibodies (Abs) were used: anti-cytochrome C (\#BV3026-3, Medical and Biological Laboratories, Nagoya City, Japan), anti-PTEN (\#9559), anti-non Ser-380/Thr 382/3836 phospho-PTEN (\#9569), anti-AKT (\#9227), anti-phospho AKT (\#9271), anti-Src-homolog protein tyrosine phosphatase (SHP-1) (\#3759) and anti-phospho SHP-1 (\#8849) (1:1000, Cell Signalling Technology, Danvers, USA); anti-CB (1:250, sc-13985, Santa Cruz Biotechnology, Inc., Dallas, USA). The following mouse monoclonal Abs were used: anti-Bid (1:1000, \#2002, Cell Signalling Technology), anti-CB $(1 \mu \mathrm{g} / \mathrm{ml}$, IM27L, Merck Millipore, Darmstadt, Germany), anti-phosphotyrosine (anti-pTyr, 1:1000, 05-947, Merck Millipore), IgG2a isotype control (NBP1-96778, Novus Biologicals) and horseradish peroxidase (HRP)-conjugated antiglyceraldehyde-3-phosphate dehydrogenase (antiGAPDH, 1:5000, G9295, Sigma Aldrich, St. Louis, USA). HRP-conjugated goat anti-rabbit (1:2000, RPN4301) and HRP-conjugated sheep anti-mouse (1:2000, NA931V) were from GE Healthcare Bio-Sciences AB (Uppsala, Sweden). Fluorescein isothiocyanate (FITC) conjugatedAnnexin V (Ann V-FITC) was from Enzo Life Sciences Inc. (Farmingdale, USA). JC-1 $(10 \mu \mathrm{g} / \mathrm{mL})$ and lysotracker $(50 \mathrm{nM})$ were from Invitrogen (San Diego,
CA, USA). 2',7'-dichlorofluorescein diacetate (DCFDA, $10 \mu \mathrm{g} / \mathrm{ml}$ ), dimethyl sulfoxide (DMSO, used as vehicle), propidium iodide (PI, $1 \mu \mathrm{g} / \mathrm{ml}$ ), 3-(4,5-dimethylthiazol-2yl)-2,5-diphenyltetrazolium bromide (MTT) and sodium orthovanadate $\left(\mathrm{Na}_{3} \mathrm{VO}_{4}, 0.25 \mathrm{mM}\right)$ were from Sigma Aldrich. Bafilomycin A (50 nM) was from Labogen S.r.l (Milan, Italy). Perifosine $(0.5,1$ and $2.5 \mu \mathrm{M})$ was purchased from Selleckchem (Houston, USA), CA074Me (CB inhibitor, $2.5 \mu \mathrm{M}$, Sigma Aldrich) and Z-VADFMK (caspase inhinitor, $10 \mu \mathrm{M}$ ) from Tocris Bioscience (Bristol, UK).

\section{MTT assay}

The colorimetric MTT assay that measures the mitochondrial conversion of the tetrazolium salt to a blue formazan salt was used to evaluate the cell viability. Briefly, 5637 and T24 BC cells $\left(3 \times 10^{4} / \mathrm{ml}\right)$ were seeded into 96-well plates and cultured with different doses of sorafenib $(2.5,10,20 \mu \mathrm{M})$ for $24 \mathrm{~h}$ at $37^{\circ} \mathrm{C}, 5 \% \mathrm{CO}_{2}$. In some experiments, cells were treated with sorafenib 20 $\mu \mathrm{M}$ for 24,48 and $72 \mathrm{~h}$. At the end of treatment, $0.8 \mathrm{mg} /$ $\mathrm{ml}$ of MTT was added to the samples and incubated for $3 \mathrm{~h}$. Then the supernatants were discarded and coloured formazan crystals, dissolved with $100 \mu \mathrm{l} /$ well of DMSO, were read by an enzyme-linked immunosorbent assay reader (BioTek Instruments, Winooski, USA). In addition, $\mathrm{BC}$ cells were treated with vehicle, sorafenib $(10 \mu \mathrm{M})$ or with perifosine $(0.5,1$ and $2.5 \mu \mathrm{M})$ alone or in combination for $24 \mathrm{~h}$. Four replicates were used for each treatment and data were represented as the average of at least three separate experiments. $\mathrm{IC}_{50}$ value, representing the concentration exerting an half-maximal inhibition of cell growth, was calculated using GraphPad Prism Software.

The synergistic activity of sorafenib and perifosine used in combination on the viability of 5637 and T24 BC cells was determined by the isobologram and CI methods (CompuSin Software, ComboSyn, Inc. Paramus, NJ 2007). The CI was used to express synergism $(\mathrm{CI}<1)$, additivity $(\mathrm{CI}=1)$ or antagonism $(\mathrm{CI}>1)$ and was calculated according to the standard isobologram equation [55].

\section{Lysosome staining by LysoTracker}

To investigate the involvement of lysosomes, $\mathrm{BC}$ cells were stained with LysoTracker-green. Briefly, 5637 and T24 cells $\left(3 \times 10^{5} / \mathrm{ml}\right)$, seeded into 6-well plates, were treated with sorafenib $(20 \mu \mathrm{M})$ for 1 and 2 h. Then LysoTracker-green probe $(50 \mathrm{nM})$ was added for $30 \mathrm{~min}$ at $37^{\circ} \mathrm{C}$. Samples were analyzed by a FACScan cytofluorimeter using the CellQuest software; fluorescence intensity was expressed in arbitrary units on logarithmic scale. 


\section{Annexin V and PI staining}

Apoptotic cell death on 5637 and T24 BC cells was evaluated using Ann V-FITC and PI staining followed by biparametric FACS analysis. Briefly cells, seeded as above described, were treated with sorafenib (10 and 20 $\mu \mathrm{M})$ or vehicle for different times and then incubated with Ann V-FITC and PI according to the manufacturer's instruction. The simultaneous staining with Ann V-FITC and the non-vital dye PI allows the discrimination of intact cells (FITC-PI-), early apoptotic (FITC $\left.{ }^{+} \mathrm{PI}^{-}\right)$and late apoptotic or necrotic cells $\left(\mathrm{FITC}^{+} \mathrm{PI}^{+}\right)$. The percentage of positive cells determined over 10,000 events was analyzed on a FACScan cytofluorimeter using the CellQuest software. In some experiments, T24 BC cells were pretreated for $30 \mathrm{~min}$ with sodium orthovanadate $(0.25 \mathrm{mM})$ [56] or Z-VAD-FMK $(10 \mu \mathrm{M})$ [28] before the treatment with sorafenib $(20 \mu \mathrm{M})$ for $24 \mathrm{~h}$. In addition, the percentage of Ann $\mathrm{V}^{+}$cells was evaluated in T24 BC cells treated with sorafenib $(20 \mu \mathrm{M})$ alone or in combination with perifosine $(2.5 \mu \mathrm{M})$ for $12 \mathrm{~h}$.

\section{Reactive Oxygen Species (ROS) production}

5637 and T24 BC cells $\left(4 \times 10^{4} / \mathrm{ml}\right)$ were seeded into 24-well plates and cultured for different times $(4,8$ and $12 \mathrm{~h})$ with sorafenib $(20 \mu \mathrm{M})$ or vehicle. Cells were washed with PBS, pulsed with DCFDA for $10 \mathrm{~min}$ at $37^{\circ} \mathrm{C}, 5 \% \mathrm{CO}_{2}$, and analyzed by FACScan cytofluorimeter using the CellQuest software. The percentage of positive cells determined over 10,000 events was analyzed on a FACScan cytofluorimeter using the CellQuest software.

\section{Mitochondrial transmembrane potential $(\Delta \Psi \mathrm{m})$}

$\Delta \Psi \mathrm{m}$ was evaluated by JC-1 staining. 5637 and T24 BC cells $\left(4 \times 10^{4} / \mathrm{ml}\right)$, seeded into 24 -well plates, were treated with sorafenib $(20 \mu \mathrm{M})$ or vehicle for different times and then incubated for $10 \mathrm{~min}$ at room temperature with JC-1. JC-1 was excited by an argon laser $(488 \mathrm{~nm})$; green $(530 \mathrm{nrn}) /$ red $(>570 \mathrm{nrn})$ emission fluorescence was collected simultaneously. Carbonyl cyanide chlorophenylhydrazone protonophore, a mitochondrial uncoupler that collapses $\Delta \Psi \mathrm{m}$ was used as positive control (data not shown). Samples were analyzed by a FACScan cytofluorimeter using the CellQuest software; fluorescence intensity was expressed in arbitrary units on logarithmic scale.

\section{Molecular docking analysis}

Molecular docking analysis was performed on Linux Red Hat Pentium4 - based platform using Autodock Vina [57] and InsightII software (Release 2005, Accelrys
Ltd., Cambridge, U.K). Human CB X-ray crystal structure (pdbID:1CSB) [58] was obtained from the Protein Data Bank [59]. Pdbqt three-dimensional structure files of sorafenib and pazopanib comparative drugs and $\mathrm{CB}$ were obtained by adding polar hydrogens and removing water from protein, and were submitted to Vina, setting a docking grid with a size of $60 \AA \times 65 \AA \times 50 \AA$, centered at the position $\mathrm{x}=21.18, \mathrm{y}=-6.05, \mathrm{z}=38.08$. Then, the most stable composite $\mathrm{CB} / \mathrm{TKI}$ drug model was refined using Discover module of InsightII, minimizing all atoms as previously reported [59]. Docking module was used to calculate total intermolecular energy $\left(\mathrm{E}_{\text {Total }}=\mathrm{E}_{\text {Elect }}+\mathrm{E}_{\mathrm{VdW}}\right)$ and Ludi module was used to calculate LUDI Score and the related predicted equilibrium dissociation constants $K_{d}$ by the standard equation LUDI Score $=-100 \times \log _{10}$ $K_{d}$ and the Energy Estimate 3 [58]. PyMOL software (DeLano Scientific LLC, San Carlos, CA, 2009-10) was used to render all the output from InsightII and to calculate the distances of hydrogen bonds as measured between the hydrogen and its assumed binding partner.

\section{Cathepsin B activity}

CB proteolytic activity was measured in 5637 and T24 BC cells at 1, 3, 6 and $12 \mathrm{~h}$ after sorafenib $(20 \mu \mathrm{M})$ treatment following the protocol described by Tchoupe and coworkers using the fluorogenic peptide Z-Arg-Arg-AMC at a final concentration of $50 \mu \mathrm{M}$. The mixture, containing $5 \mu \mathrm{g}$ of protein lysate, was incubated in $50 \mathrm{mM}$ phosphate buffer $\mathrm{pH}$ 6.0, $1 \mathrm{mM}$ EDTA and $2 \mathrm{mM}$ dithiothreitol for 1 $\mathrm{h}$ at $30^{\circ} \mathrm{C}$. The fluorescence of the hydrolyzed 7 -amino4-methyl-coumarin $(\mathrm{AMC}, \lambda \mathrm{exc}=365 \mathrm{~nm}, \lambda \mathrm{em}=449 \mathrm{~nm})$ was detected on a SpectraMax Gemini XPS microplate reader (Molecular Devices). In some experiments, CB activity was evaluated in T24 cells pretreated for $30 \mathrm{~min}$ with $0.25 \mathrm{mM}$ of sodium orthovanadate and then treated for 1,3 and $6 \mathrm{~h}$ with sorafenib $(20 \mu \mathrm{M})[60]$.

\section{Western blot}

5637 and T24 BC cells, untreated or treated for different times with sorafenib $(20 \mu \mathrm{M})$, vehicle or pretreated for $30 \mathrm{~min}$ with sodium orthovanadate $(0.25$ $\mathrm{mM})$, before the treatment with sorafenib $(20 \mu \mathrm{M})$ for 24 $\mathrm{h}$, were lysed in lysis buffer ( $1 \mathrm{M}$ Tris $\mathrm{pH} 7.4,1 \mathrm{M} \mathrm{NaCl}$, $10 \mathrm{mM}$ EGTA, $100 \mathrm{mM} \mathrm{NaF}, 100 \mathrm{mM} \mathrm{Na}_{3} \mathrm{VO}_{4}, 100 \mathrm{mM}$ phenylmethylsulfonyl fluoride, $2 \%$ deoxycholate, $100 \mathrm{mM}$ EDTA, $10 \%$ Triton X-100, 10\% glycerol, 10\% SDS, 0.1 $\mathrm{M} \mathrm{Na}_{4} \mathrm{P}_{2} \mathrm{O}_{7}$ ) containing protease inhibitor cocktail (SigmaAldrich) by using a Mixer Mill MM300 (Qiagen, Hilden, Germany). Lysates were separated on SDS polyacrylamide gel and transferred onto Hybond-C extra membranes (GE Healthcare). Blots were incubated with blocking solution and the primary $\mathrm{Ab}$ anti-CB followed by the appropriate HRP-conjugated secondary Abs according to the specific 
datasheet. In some experiments lysates coming from T24 BC cells treated for different times with $(20 \mu \mathrm{M})$ sorafenib alone or in combination with bafilomycin A [27] or CA074Me were incubated with: anti-SHP-1, antipSHP-1, anti-PTEN, anti-non pPTEN, anti-AKT, antipAKT and anti-BID. In addition, we also evaluated the cytochrome $\mathrm{c}$ and $\mathrm{CB}$ in the cytosolic fraction of 5637 and T24 cells. Briefly, untreated or sorafenib-treated cells for different times $(1,3$ and $6 \mathrm{~h})$ were washed in ice-cold PBS and the resulting pellet was resuspended in $0.12 \mathrm{ml}$ of lysis buffer ( $20 \mathrm{mM}$ HEPES), $10 \mathrm{mM}$ $\mathrm{KCl}, 1.5 \mathrm{mM} \mathrm{MgCl}, 1 \mathrm{mM}$ EDTA, $1 \mathrm{mM}$ EGTA, $1 \mathrm{mM}$ DTT and $0.1 \mathrm{mM}$ PMSF) supplemented with protease inhibitor cocktail. After sitting on ice for $15 \mathrm{~min}$, cells were disrupted by 60 times douncing in a mini-potter. The nuclei were pelletted at $1000 \mathrm{~g}$ for $5 \mathrm{~min}$ at $4^{\circ} \mathrm{C}$ and the supernatants were separated and centrifuged for 40 $\mathrm{min}$ at $80000 \mathrm{~g}$. Then, supernatants loaded onto a $12 \%$ SDS-PAGE were transferred and incubated with anticytochrome c $(0.5 \mu \mathrm{g} / \mathrm{ml})$ or $-\mathrm{CB}(250 \mathrm{ng} / \mathrm{mL}) \mathrm{mAbs}$ followed by HRP-conjugated anti-mouse (1:2000) $\mathrm{Ab}$. GAPDH expression levels were used as loading control. The detection was performed using the LiteAblot ${ }^{\circledR}$ PLUS or the LiteAblot ${ }^{\circledR}$ TURBO (EuroClone, Milano, Italy) kits and densitometric analysis was carried out by evaluating three independent experiments by a Chemidoc using the Quantity One software (BioRad, Hercules, USA).

\section{Immunoprecipitation (IP)}

Cell lysates $(300 \mu \mathrm{g})$ from $\mathrm{T} 24$ and $5637 \mathrm{BC}$ cells, untreated or treated for 1 and $3 \mathrm{~h}$ with sorafenib $(20 \mu \mathrm{M})$ or for $3 \mathrm{~h}$ with perifosine $(0.5,1$ and 2.5 $\mu \mathrm{M})$, were immunoprecipitated using anti-CB mAb following the Immunoprecipitation Kit Dynabeads $\mathbb{}$ Protein A instructions (Life Technologies, Monza, Italy). Immunoprecipitated samples were then applied on SDSPAGE, transferred, and blotted with anti-pTyr and with polyclonal anti-CB Abs according to the datasheet. As IP control, isotype-matched IgG was used. Detection was performed as described above.

\section{Statistical analysis}

The statistical significance was determined by Student's t-test and by one way ANOVA. No statistical significant difference was found between untreated and vehicle (DMSO)-treated cells or comparing different times of vehicle-treatment each other (data not shown).

\section{CONFLICTS OF INTEREST}

Authors declare no conflicts of interest

\section{GRANT SUPPORT}

This study was supported by Fondazione Italiana Ricerca sul Cancro (11095) and University of Camerino (Fondo di Ateneo per la Ricerca 2012-2013).

\section{REFERENCES}

1. Rose A, Grandoch M, vom Dorp F, Rübben H, Rosenkranz A, Fischer JW, Weber AA. Stimulatory effects of the multikinase inhibitor sorafenib on human bladder cancer cells. Br J Pharmacol. 2010; 160: 1690-1698.

2. Wilhelm SM1, Carter C, Tang L, Wilkie D, McNabola A, Rong H, Chen C, Zhang X, Vincent P, McHugh M, Cao Y, Shujath J, Gawlak S et al. BAY 43-9006 exhibits broad spectrum oral antitumor activity and targets the RAF/MEK/ ERK pathway and receptor tyrosine kinases involved in tumor progression and angiogenesis. Cancer Res. 2004; 64: 7099-7109.

3. Dreicer R, Li H, Stein M, DiPaola R, Eleff M, Roth BJ, Wilding G. Phase 2 trial of sorafenib in patients with advanced urothelial cancer: a trial of the Eastern Cooperative Oncology Group. Cancer. 2009; 115: 40904095.

4. Sridhar SS, Winquist E, Eisen A, Hotte SJ, McWhirter E, Tannock IF, Mukherjee SD, Wang L, Blatter C, Whrigh JJ, Moore MJ. A phase II trial of sorafenib in first-line metastatic urothelial cancer: a study of the PMH phase II Consortium. Invest New Drugs. 2011; 29: 1045-1049.

5. Krege S, Rexer H, Von Dorp F, de Geeter P, Klotz T, Retz M, Heidenreich A, Kuhn M, Kamradt J, Feyerabend S, Wulfing C, Zastrow S, Albers P et al. Prospective randomized double-blind multicenter phase II study compring chemotherapy with gemcitabine and cispltin plus sorafenib vs gemcitabine and cisplatin plus placebo in locally advanced and/or metastasized urothelial cancer - SUSE - (AUO-AB 31/05). BJU. 2013; 113: 429-436.

6. Bambury RM, Rosenberg JE. Advanced urothelial carcinoma:overcoming treatment resistance through novel treatment approaches. Frontiers Pharmacol. 2013; 4: 1-7.

7. Platt FM, Hurst CD, Taylor CF, Gregory WM, Harnden P, Knowles MA. Spectrum of phosphatidylinositol 3-kinase pathway gene alterations in bladder cancer. Clin Cancer Res. 2009; 15: 6008-6017.

8. Chen M, Gu J, Delclos GL, Killary AM, Fan Z, Hildebrandt MA, Chamberlain RM, Grossman HB, Dinney CP, Wu X. Genetic variations of the PI3K-AKT-mTOR pathway and clinical outcome in muscle invasive and metastatic bladder cancer patients. Carcinogenesis. 2010; 31: 1387-1391.

9. Chen KF, Chen HL, Tai WT, Feng WC, Hsu CH, Chen PJ, Cheng AL. Activation of phosphatidylinositol 3-kinase/Akt signaling pathway mediates acquired resistance to sorafenib in hepatocellular carcinoma cells. J Pharmacol Exp Ther. 2011; 337: 155-161. 
10. Ruan ZP, Xu R, Lv Y, Tian T, Wang WJ, Guo H, Nan KJ. PTEN enhances the sensitivity of human hepatocellular carcinoma cells to sorafenib. Oncol Res. 2012; 20: 113-121.

11. Ching CB, Hansel DE. Expanding therapeutic targets in bladder cancer: the PI3K/Akt/mTOR pathway. Lab Invest. 2010; 90: 1406-1414.

12. Kompier LC, Lurkin I, van der Rhijn AaMN, dan der Kwast TH, Zwarthoff EC. FGFR3, HRAS, KRAS, NRAS and PIK3CA mutations in bladder cancer and their potential as biomarkers for surveillance and therapy. Plos ONE. 2010; 5: e13821.

13. Chalhoub N, Baker SJ. PTEN and the PI3-kinase pathway in cancer. Annu Rev Pathol. 2009; 4: 127-150.

14. Tai WT, Shiau CW, Chen HL, Liu CY, Lin CS, Cheng AL, Chen PJ, Chen KF. Mcl-1-dependent activation of Beclin 1 mediates autophagic cell death induced by sorafenib and SC-59 in hepatocellular carcinoma cells. Cell Death Dis. 2013; 4: e485.

15. Engelman JA. Targeting PI3K signaling in cancer: opportunities, challenges and limitations. Nat Rev Cancer. 2009; 9: 550-562.

16. Ross AH, Gericke A. Phosphorylation keeps PTEN phosphatase closed for business. Proc Natl Acad Sci U S A. 2009; 106: 1297-1298.

17. Ferri KF, Kroemer G. Organelle-specific initiation of cell death pathways. Nat Cell Biol. 2001;3 :E255-263.

18. Aits S, Jäättelä M. Lysosomal cell death at a glance. J Cell Sci. 2013; 126: 1905-1912.

19. Kroemer G, Jäättelä M. Lysosomes and autophagy in cell death control. Nat Rev Cancer. 2005; 5: 886-897.

20. Kirkegaard T, Jäättelä M. Lysosomal involvement in cell death and cancer. Biochim Biophys Acta. 2009; 1793: 746754.

21. McGrath ME. The lysosomal cysteine proteases. Annu Rev Biophys Biomol Struct. 1999; 28: 181-204.

22. Ha SD, Martins A, Khazaie K, Han J, Chan BM, Kim So. Cathepsin B is involved in the trafficking of TNFalpha-containing vesicles to the plasma membrane in macrophages. J Immunol. 2008; 181: 690-697.

23. Halle A, Hornung V, Petzold GC, Stewart CR, Monks BG, Reinheckel T, Fitzgerald KA, Latz E, Moore KJ, Golenbock DT. The NALP3 inflammosome is involved in the innate immune response to amyloid beta. Nat Immunol. 2008; 9 : 857-865.

24. Willingham SB, Bergstralh DT, O'Connor W, Morrison AC, Taxman DJ, Duncan JA, Barnoy S, Venkatesan MM, Flavell RA, Deshmukh M, Hoffman HM, Ting JP. Microbial pathogen-induced necrotic cell death mediated by the inflammosome component CIAS1/cryopyrin/NLRP3 and ASC. Cell Host Microbe. 2007; 2: 147-159.

25. Turk B, Stoka V, Rozman-Pungercar J, Cirman T, DrogaMazovec G, Oresić K, Turk V. Apoptotic pathways: involvement of lysosomal proteases. Biol Chem. 2002; 383:
1035-1044.

26. Hsu SF, Hsu CC, Cheng BC, Lin CH. Cathepsin B is involved in the heat shock induced cardiomyocytes apoptosis as well as the anti-apoptosis effect of HSP-70. Apoptosis. 2014;19:1571-80.

27. Beckham SA, Piedrafita D, Phillips CI, Samarawickrema N, Law RH, Smooker PM, Quinsey NS, Irving JA, Greenwood D, Verhelst SH, Bogyo M, Turk B, Coetzer TH et al. A major cathepsin B protease from the liver fluke Fasciola hepatica has atypical active site features and a potential role in the digestive tract of newly excysted juvenile parasites. Int J Biochem Cell Biol. 2009; 41: 1601-1612.

28. Santoni M, Amantini C, Morelli MB, Liberati S, Farfariello V, Nabissi M, Bonfili L, Eleuteri AM, Mozzicafreddo M, Burattini L, Berardi R, Cascinu S, Santoni G. Pazopanib and sunitinib trigger autophagic and non-autophagic death of bladder tumour cells. Br J Cancer. 2013; 109: 1040-1050.

29. Sandes E, Lodillinsky C, Cwirenbaum R, Argüelles C, Casabé A, Eiján AM. Cathepsin B is involved in the apoptosis intrinsic pathway induced by Bacillus CalmetteGuérin in transitional cancer cell lines. Int J Mol Med. 2007; 20: 823-828.

30. Yang F, Brown C, Buettner R, Hedvat M, Starr R, Scuto A, Schroeder A, Jensen M, Jove R. Sorafenib induces growth arrest and apoptosis of human glioblastoma cells via dephosphorylation of STAT3. Mol Cancer Ther. 2010; 9: 953-962.

31. Chen KF, Tai WT, Hsu CY, Huang JW, Liu CY, Chen PJ, Kim I, Shiau CW. Blockade of STAT3 activation by sorafenib derivatives through enhancing SHP-1 phosphatase activity. Eur J Med Chem. 2012; 55: 220-227

32. Liu CY, Tseng LM, Su JC, Chang KC, Chu PY, Tai WT, Shiau CW, Chen KF. Novel sorafenib analogues induce apoptosis through SHP-1 dependent STAT3 inactivation in human breast cancer cells. Breast Cancer Res. 2013; 15: R63.

33. Huck O, Elkaim R, Davideau JL, Tenenbaum H. Porphyromonas gingivalis and its lipopolysaccharide differentially regulate the expression of cathepsin B in endothelial cells. Mol Oral Microbiol. 2012; 27: 137-148.

34. Locatelli SL, Giacomini A, Guidetti A, Cleris L, Mortarini R, Anichini A, Gianni AM, Carlo-Stella C. Perifosine and sorafenib combination induces mitochondrial cell death and antitumor effects in NOD/SCID mice with Hodgkin lymphoma cell line xenografts. Leukemia. 2013; 27: 16771687.

35. Guicciardi ME, Deussing J, Miyoshi H, Bronk SF, Svingen PA, Peters C, Kaufmann SH, Gores GJ. Cathepsin B contributes to TNF-alpha-mediated hepatocyte apoptosis by promoting mitochondrial release of cytochrome c. J Clin Invest. 2000; 106: 1127-1137.

36. Brunk UT, Neuzil J, Eaton JW. Lysosomal involvement in apoptosis. Redox Rep. 2001; 6: 91-97.

37. Boya P, Andreau K, Poncet D, Zamzami N, Perfettini JL, 
Metivier D, Ojcius DM, Jaattela M, Kroemer G. Lysosomal membrane permeabilization induces cell death in a mitochondrion-dependent fashion. J Exp Med. 2003; 197: 1323-1334.

38. Droga-Mazovec G, Bojic L, Petelin A, Ivanova S, Romih R, Repnik U, Salvesen GS, Stoka V, Turk V, Turk B. Cysteine cathepsins trigger cspase-dependent cell death through cleavage of Bid and antiapoptotic Bcl-2 homologues. J Biol Chem. 2008; 283: 19140-19150.

39. Erdal H, Berndtsson M, Castro J, Brunk U, Shoshan $\mathrm{MC}$, Linder S. Induction of lysosomal membrane permeabilization by compounds that activate p53independent apoptosis. Proc Natl Acad Sci U S A. 2005; 102: 192-197.

40. Green DR, Kroemer G. Pharmacological manipulation of cell death: clinical applications in sight? J Clin Invest. 2005; 115: 2610-2617.

41. Barbosa CM, Oliveira CR, Nascimento FD, Smith MC, Fausto DM, Soufen MA, Sena E, Araújo RC, Tersariol IL, Bincoletto C, Caires AC. Biphosphinic palladacycle complex mediates lysosomal-membrane permeabilization and cell death in K562 leukaemia cells. Eur J Pharmacol. 2006; 542: 37-47.

42. Turk B, Stoka V. Protease signalling in cell death: caspases versus cysteine cathepsins. FEBS Lett. 2007; 581: 27612767.

43. Ollinger K, Brunk UT. Cellular injury induced by oxidative stress is mediated through lysosomal damage. Free Radic Biol Med. 1995; 19: 565-574.

44. Antunes F, Cadenas E, Brunk UT. Apoptosis induced by exposure to a low steady-state concentration of $\mathrm{H} 2 \mathrm{O} 2$ is a consequence of lysosomal rupture. Biochem J. 2001; 356: 549-555.

45. Stoka V, Turk B, Schendel SL,Kim T-H, Cirman T, Snipas S-J, Ellerby LS, Bredesen D, Freeze H, Abrahamanson M, Bromme D, Krajewski S, Reed JC, Yin X-M, Turk V, Salvesen GS. Lysosomal protease pathways to apoptosis cleavage of Bid, not procaspases is the most likely route. J Biol Chem. 2001; 276: 3149-3157.

46. Rafiq K, Kolpakov MA, Abdelfettah M, Streblow DN, Hassid A, Dell'Italia LJ, Sabri A. Role of protein-tyrosine phosphatase SHP2 in focal adhesion kinase down-regulation during neutrophil cathepsin G-induced cardiomyocytes anoikis. J Biol Chem. 2006; 281: 19781-19792.

47. Honma Y, Shimizu S, Takehara T, Harada M. Sorafenib enhances proteasome inhibitor-induced cell death via inactivation of Akt and stress-activated protein kinases. J Gastroenterol. 2014; 49: 517-526.

48. Plaza-Menacho I, Mologni L, Sala E, Gambacorti-Passerini C, Magee AI, Links TP, Hofstra RM, Barford D, Isacke $\mathrm{CM}$. Sorafenib functions to potently suppress RET tyrosine kinase activity by direct enzymatic inhibition and promoting RET lysosomal degradation independent of proteasomal targeting. J Biol Chem. 2007; 282: 29230-29240.

49. Wei Y, Ma Y, Zhao Q, Ren Z, Li Y, Hou T, Peng H. New use for an old drug: inhibiting ABCG2 with sorafenib. Mol Cancer Ther. 2012; 11: 1693-1702.

50. Dasmamapatra GP, Didolkar P, Alley M, Ghosh S, Sausville EA, Roky KK. In vitro combinatiom therapy with perifosine and UCN-9 demonstrates synergism against prostate (PC-3) and lung (A549) epithelial adenocarcinoma cell lines. Clin Cancer Res. 2004; 10: 5242-5252.

51. Hideshima T, Catley L, Yasui H, Ishitsuka K, Raje N, Mitsiades C, Podar K, Munshi NC, Chauhan D, Richarson PG, Anderson KC. Perifosine, an oral bioactive novel alkhylphospholipid, inhibits Akt and induces in vitro and in vivo cytotoxicity in human multiple myeloma cells. Blood. 2006; 107: 4053-4062.

52. Fei HL, Chen G, Wang JM, Wang FZ. Perifosine induced cell cycle arrest and apoptosis in human hepatocellular carcinoma cell lines by blockade of Akt phosphorylation. Cytotechnology. 2010; 62: 448-460.

53. Srivastava N, Cho DC. Perifosine in renal cell carcinoma. Expert Opin Investig Drugs. 2013; 22: 285-291.

54. Kondapaka SB, Singh SS, Dasmahapatra GP, Sausville EA, Roy KK. Perifosine a novel alkylphospholipid, inhibits protein kinase B activation. Mol Cancer Ther. 2003; 2: 1093-1104.

55. Chou TC. Theoretical basis, experimental design, and computerized simulation of synergism and antagonism in drug combination studies. Pharmacol Rev. 2006; 58: 621681.

56. Yang F, Brown C, Buettner R, Hedvat M, Starr R, Scuto A, Schroeder A, Jensen M, Jove R. Sorafenib induces growth arrest and apoptosis of human glioblastoma cells through the dephosphorylation of signal transducers and activators of transcription 3. Mol Cancer Ther. 2010; 9: 953-962.

57. Trott O, Olson AJ. AutoDock Vina: improving the speed and accuracy of docking with a new scoring function, efficient optimization and multithreading. J Comput Chem. 2010; 31: 455-461.

58. Turk D, Podobnik M, Popovic T, Katunuma N, Bode W, Huber R, Turk V. Crystal structure of cathepsin B inhibited with CA030 at 2.0-A resolution: A basis for the design of specific epoxysuccinyl inhibitors. Biochemistry. 1995; 34 : 4791-4797.

59. Mozzicafreddo M, Cuccioloni M, Cecarini V, Eleuteri AM, Angeletti M. Homology modeling and docking analysis of the interaction between polyphenols and mammalian $20 \mathrm{~S}$ proteasomes. J Chem Inf Model, 2009; 49: 401-409.

60. Tchoupe JR, Moreau T, Gauthier F, Bieth JG. Photometric or fluorometric assay of cathepsin B, L and $U$ and papain using substrates with an aminotrifluoromethylcoumarin leaving group. Biochim Biophys Acta. 1991; 1076: 149151. 